\title{
Bio-efficacy of Newer Insecticides and Biopesticides against Thrips, Scirtothrips dorsalis Hood in Pomegranate
}

\author{
S. R. Shinde ${ }^{1}$, A. K. Bhowmick ${ }^{1}$, A. K. Shukla ${ }^{1}$ and Kuldeep Sharma ${ }^{2} *$ \\ ${ }^{1}$ Department of Entomology, Jawahar Lal Nehru Krishi Vishwa Vidyalaya, Jabalpur, Madhya \\ Pradesh- 482004, India \\ ${ }^{2}$ Department of Entomology, Maharana Pratap University of Agriculture and Technology, \\ Udaipur, Rajasthan- 313001, India \\ *Corresponding author
}

Keywords

Bio-efficacy, Newer insecticides, Bio pesticides, Thrips, Pomegranate

Article Info

Accepted:

12 November 2019

Available Online:

10 December 2019
Investigations on "Bio-efficacy of newer insecticides and bio pesticides against thrips, Scirtothrips dorsalis Hood on Pomegranate" were conducted at pomegranate Research Block H-25 of ICAR-NRCP, Solapur on cv. 'Bhagawa' during Hasta Bahar seasons in 2016-17 and 2017-18. Statistically data was designed in RBD with eight treatment and three replications. Observations were recorded at three, seven and ten days after spraying. On the basis of number of thrips found per plant after all the five sprays the treatment of Chlorantriniliprole $8.8 \%$ + Thiomethoxam $17.5 \%$ SC (82.62\%) was found to be the most effective in three, seven and ten days after spraying recorded $14.12,14.60$ and 18.70 thrips per plant respectively. The minimum effectiveness was noticed in Karanj oil + Neem oil mixture recoded 22.41, 21.98 and 26.87thrips per plant after three, seven and ten days after spraying respectively. The order of effectiveness of these treatments in descending order was Chlorantriniliprole $8.8 \%+$ Thiomethoxam $17.5 \%$ SC> Thiomethoxam $12.5 \%$ + Lambda-cyhalothrin 9.5\% ZC > Lambda-cyhalothrin 4.6\% + Chlorantriniliprole 9.3\% ZC > Buprofezin 15\% + Acephate 35\% WP > Azadirachtin 300 PPM > Karanj oil > Karanj oil + Neem oil > Control. The chemical treatments were more effective than bio pesticides which was treated in this experiment.

\section{Introduction}

The pomegranate (Punica granatum L.) is one of the oldest known edible fruits. This is emerging as one of the commercially important fruit crops of tropical and subtropical regions of the world. The name pomegranate is derived from two Latin words 'pōmum' (apple) and grānātum (seeded). It belongs to the family 'Lythraceae' formerly was placed in 'Punicaceae'. The genus Punica includes two species, Punica granatum the edible pomegranate native to Iran and northern India and the other being Punica protopunica, 
which is native to the island of Socotra and is not of economic importance. In India, pomegranate is popularly known as Anar, Dalimb, Dalima or Dodima in different states. It is thought to be indigenous to Iran, where it was first cultivated during 2000 B.C. (Evreinoffa, 1949). It spread to the Mediterranean countries and today it is being cultivated extensively in the Mediterranean countries (Tunisia, Turkey, Egypt, Spain, and Morocco), Iran, Afghanistan, India, and to some extent in the United States (California), China, Japan, and Russia. It is an important fruit crop of arid and semiarid regions of the world. Pomegranate cultivation is one of the most remunerative and attractive farming enterprises in the arid and semi-arid regions of India. Several varieties viz. Alandi (Vadki), Dholka, pomegranate GKVK1, IIHR Selection, Spanish Ruby, Jyothi, Ruby, Muskat Red, G-13, Mridula, Ganesh, Arakta and Bhagawa, Super Bhagawa etc. are grown in different regions but 'Bhagawa' is the most popular variety today.

India is the largest producer of pomegranate with production of 28.45 lakh MT through area of 2.34 lakh ha (NHB, 2017-18), with $70 \%$ area in Maharashtra, followed by Gujarat, Karnataka, Telangana, Andhara Pradesh, Rajasthan, Madhya Pradesh and few other states. Thrips are important pest of pomegranate deteriorating fruit quality and it is found throughout year. It has become a major constraint in the production of appropriate quality fruits of pomegranate for domestic and export markets. Pomegranate thrips, Scirtothrips dorsalis Hood is the most widespread, polyhouse and destructive pest with a wide range of host plants viz., vegetables, flowers and fruits. Incidence of the pest is found in every season and more than 70 per cent infestation can be observed on crop. It attacks the developing fruits, flowers and leaves, causes heavy losses to the growers by deteriorating fruit quality.

\section{Materials and Methods}

Assess the bio-efficacy of different molecules of insecticides and bio pesticides against thrips infesting pomegranate. The trial was carried out in pomegranate Research Block $\mathrm{H}-25$ of ICAR-NRCP, Solapur on cv. 'Bhagawa' during Hasta Bahar seasons in 2016-17 and 2017-18 against thrips species Scirtothrips dorsalis Hood. Standard fertilizer and disease management practices were followed throughout the trial period. The experiment was laid out in a Randomized Block Design (RBD) with eight treatments (insecticides) including untreated control, each treatment replicated thrice. Total 72 plants were treated each spray having $5.5 \mathrm{ft}^{2}$ plant to pant and $8 \mathrm{ft}^{2}$ plant to plant distance was maintained. The Pomegranate variety 'Bhagawa' recommended for this region was used for the experiment having 2.5 years old. Five spray at 15 days interval was taken and observation recorded at 3,7 and 10 days after spraying (Table 1).

\section{Preparation of spray solution}

The insecticidal spray solutions of desired concentrations were prepared by adopting the following formula: $\mathrm{N}_{1} \mathrm{~V}_{1}=\mathrm{N}_{2} \mathrm{~V}_{2}$ (where $\mathrm{N}_{1}=$ Concentration (EC) of available pesticide; $\mathrm{V}_{1}=$ Volume of Available Pesticide; $\mathrm{N}_{2}=$ required concentration of pesticide to be prepared; $V_{2}=$ Volume of solution required for application).

Amount of pesticide $=$

\section{Volume of spray solution (liter) \\ $\times$ Per cent strength of pesticide solution to be sprayed \\ per cent strength of pesticide given (a. i./ $/ 1$ or $\mathrm{kg}$ )}

\section{Method of observation}

In all 5 sprays at 15 days interval were taken. First spray was done at new sprouting of twigs after pruning and continued till maturity of 
rind of fruits i.e. about 70- 80 day after defoliation. Data on thrips population and infestation symptoms were recorded at 3, 7 and 10 days of spraying. Thrips were tapped on white card sheet for ease of observation. Actual numbers of thrips dropped on the sheet were counted. Observations were recorded from Twigs from each plant. Four twigs were selected from different directions (SouthWest-North-East) and recorded actual number of thrips observed on twigs. Calculated number of thrips population recorded per plant on four directions.

\section{Results and Discussion}

The experimental findings are presented in here under.

\section{Incidence of thrips on pomegranate prior to first spraying}

The data on average number of thrips recorded one day before first application of insecticides under the head pretreatment count are presented in table 2 and figure 1 . The data presented in table 2 showed that average number of thrips one day before the first application of insecticides varied from 7.33 to 9.22 thrips/plant. These observations on incidence of thrips taken one day before the first application of insecticides were statistically significant at $5 \%$ level of significance, suggesting that the incidence of thrips on pomegranate was not at uniform distribution. At initial stage of sprouting new leaves after pruning there is a smaller number of leaves and also size of leaves are small.

Therefore, pre count observations are less than treated observation. Pre count observations were taken one day before first spray only. Bio-efficacy of different against pomegranate thrips was recorded in year 2017 and 2018 is looks similar among two years. In both year Chlorantriniliprole $8.8 \%+$ Thiomethoxam $17.5 \%$ SC recorded lowest number of thrips on plant while in bio pesticides Azadirachtin 300 PPM can able to maintain lower thrips per plant than others.

\section{Three days after spraying}

The pooled data presented in table 2 and figure 1 revealed that the population of $S$. dorsalis among the different treatments was observed significant in three, seven and ten days after spraying of first spray. However, at three days after spraying the lowest population of $S$. dorsalis is noticed in Chlorantriniliprole $8.8 \%$ + Thiomethoxam $17.5 \%$ SC (14.12 thrips/plant) which was found superior over other treatments followed by Lambdacyhalothrin $4.6 \%$ + Chlorantriniliprole $9.3 \%$ ZC (15.39 thrips/ plant), Thiomethoxam $12.5 \%$ + Lambda-cyhalothrin 9.5\% ZC (15.49 thrips/plant) and Buprofezin 15\% + Acephate $35 \%$ WP (16.62 thrips/plant) all are found at par each other.

Table.1 Treatment details

\begin{tabular}{|c|c|l|c|}
\hline Sl. No. & Tr. No. & \multicolumn{1}{|c|}{ Treatment Details } & Dose (per 10 liters of water) \\
\hline 1 & $\mathrm{~T}_{1}$ & Buprofezin 15\%+ Acephate 35\% WP & $04 \mathrm{mg}$ \\
\hline 2 & $\mathrm{~T}_{2}$ & Thiomethoxam 12.5\% + Lambda-cyhalothrin 9.5\% ZC & $04 \mathrm{ml}$ \\
\hline 3 & $\mathrm{~T}_{3}$ & Lambda-cyhalothrin 4.6\%+Chlorantriniliprole 9.3\% ZC & $04 \mathrm{ml}$ \\
\hline 4 & $\mathrm{~T}_{4}$ & Chlorantriniliprole 8.8 \%+ Thiomethoxam 17.5\% SC & $04 \mathrm{ml}$ \\
\hline 5 & $\mathrm{~T}_{5}$ & Azadirachtin 300 PPM & $20 \mathrm{ml}$ \\
\hline 6 & $\mathrm{~T}_{6}$ & Karanj oil & $22 \mathrm{ml}$ \\
\hline 7 & $\mathrm{~T}_{7}$ & Karank oil + Neem oil & $10+12 \mathrm{ml}$ \\
\hline 8 & $\mathrm{~T}_{8}$ & Control \\
\hline
\end{tabular}


Table.2 Bio-efficacy of newer insecticides and biopesticides against thrips, Scirtothrips dorsalis Hood in pomegranate crop during 2017 and 2018 (pooled)

\begin{tabular}{|c|c|c|c|c|c|c|c|c|c|c|c|c|}
\hline \multirow{3}{*}{$\begin{array}{l}\text { Tr. } \\
\text { No. }\end{array}$} & \multirow[t]{3}{*}{ Treatment Details } & \multirow{3}{*}{$\begin{array}{l}\text { Dose } \\
\text { (per } 10 \\
\text { lit.) }\end{array}$} & \multicolumn{10}{|c|}{ Infestation of thrips on pomegranate } \\
\hline & & & \multirow[t]{2}{*}{$\begin{array}{c}\text { Pre } \\
\text { count }\end{array}$} & \multicolumn{3}{|c|}{$\begin{array}{c}\text { infestation of thrips on } \\
\text { pomegranate in } 2017\end{array}$} & \multicolumn{3}{|c|}{$\begin{array}{c}\text { infestation of thrips on } \\
\text { pomegranate in } 2018\end{array}$} & \multicolumn{3}{|c|}{$\begin{array}{c}\text { Pooled data of } \\
\text { infestation of thrips on } \\
\text { pomegranate }\end{array}$} \\
\hline & & & & $\begin{array}{c}3 \\
\text { DAS }\end{array}$ & $\begin{array}{c}7 \\
\text { DAS }\end{array}$ & $\begin{array}{c}10 \\
\text { DAS }\end{array}$ & $\begin{array}{c}3 \\
\text { DAS }\end{array}$ & $\begin{array}{c}7 \\
\text { DAS }\end{array}$ & $\begin{array}{c}10 \\
\text { DAS }\end{array}$ & 3 DAS & 7 DAS & $\begin{array}{c}10 \\
\text { DAS }\end{array}$ \\
\hline 1 & $\begin{array}{l}\text { Buprofezin 15\%+ } \\
\text { Acephate 35\% WP }\end{array}$ & $4.00 \mathrm{mg}$ & 7.33 & 13.69 & 17.89 & 23.26 & 19.55 & 14.69 & 19.00 & 16.62 & 16.69 & 21.13 \\
\hline 2 & $\begin{array}{c}\text { Thiomethoxam } 12.5 \%+ \\
\text { Lambda-cyhalothrin } 9.5 \% \\
\text { ZC }\end{array}$ & $04 \mathrm{ml}$ & 8.11 & 12.15 & 17.60 & 21.09 & 18.82 & 13.67 & 19.07 & 15.49 & 15.63 & 20.08 \\
\hline 3 & $\begin{array}{c}\text { Lambda-cyhalothrin } 4.6 \% \\
\text { + Chlorantriniliprole } \\
9.3 \% \mathrm{ZC}\end{array}$ & $04 \mathrm{ml}$ & 7.443 & 11.18 & 19.82 & 23.02 & 19.60 & 13.55 & 19.78 & 15.39 & 16.29 & 21.40 \\
\hline 4 & $\begin{array}{c}\text { Chlorantriniliprole8.8 \% } \\
+ \text { Thiomethoxam } 17.5 \\
\% \text { SC }\end{array}$ & $04 \mathrm{ml}$ & 7.11 & 10.49 & 16.87 & 20.33 & 17.75 & 12.33 & 17.07 & 14.12 & 14.60 & 18.70 \\
\hline 5 & Azadirachtin 300 PPM & $20 \mathrm{ml}$ & 9.22 & 16.20 & 24.00 & 23.67 & 20.75 & 16.78 & 24.53 & 18.48 & 20.99 & 24.51 \\
\hline 6 & Karanj oil & $22 \mathrm{ml}$ & 8.333 & 17.96 & 25.65 & 24.20 & 21.38 & 18.58 & 26.33 & 19.66 & 22.11 & 25.27 \\
\hline 7 & Karanj oil + Neem oil & $22 \mathrm{ml}$ & 8.557 & 19.93 & 25.20 & 29.20 & 24.89 & 19.96 & 25.36 & 22.41 & 21.98 & 26.87 \\
\hline \multirow[t]{5}{*}{8} & Control & - & 9 & 19.69 & 27.71 & 31.00 & 26.73 & 21.82 & 27.82 & 23.21 & 24.77 & 29.41 \\
\hline & C.D. & - & N/A & 1.167 & 3.627 & 3.85 & 2.729 & 1.525 & 3.744 & 1.597 & 1.683 & 2.558 \\
\hline & $\mathrm{SE}(\mathrm{m})$ & - & 0.705 & 0.381 & 1.184 & 1.257 & 0.891 & 0.498 & 1.222 & 0.521 & 0.55 & 0.835 \\
\hline & $\mathrm{SE}(\mathrm{d})$ & - & 0.997 & 0.539 & 1.675 & 1.778 & 1.26 & 0.704 & 1.729 & 0.737 & 0.777 & 1.181 \\
\hline & C.V. & - & 15.005 & 4.353 & 9.391 & 8.897 & 7.286 & 5.252 & 9.465 & 4.97 & 4.976 & 6.178 \\
\hline
\end{tabular}


Fig.1 Bio-efficacy of newer insecticides and biopesticides against thrips, Scirtothrips dorsalis Hood in pomegranate crop during 2017 and 2018 (pooled)

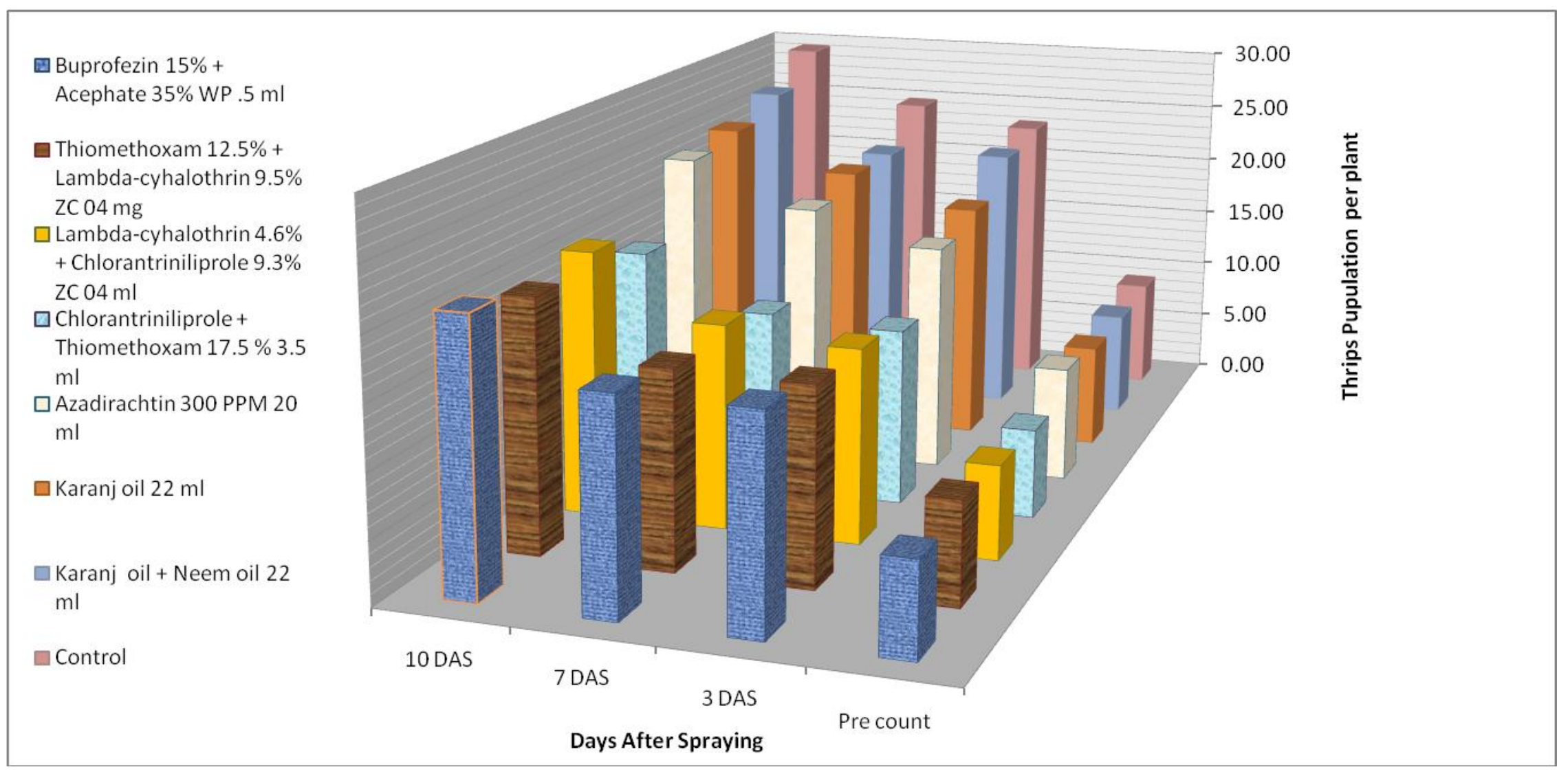


Among bio pesticides Azadirachtin 300 PPM recorded lowest pest population (18.48 thrips/plant) followed by Karanj oil (19.66 thrips/plant) and Karanj oil + Neem oil (22.41 thrips/plant). All the treatments are found superior over control (water spray) (23.21 thrips/ plant).

\section{Seven days after spraying}

At seven days after spraying Chlorantriniliprole $8.8 \%$ + Thiomethoxam $17.5 \% \mathrm{SC}$ maintain minimum thrips population i.e. 14.60 thrips/plant followed by Thiomethoxam $12.5 \%$ + Lambda-cyhalothrin 9.5\% ZC (15.63 thrips /plant), Lambdacyhalothrin $4.6 \%$ + Chlorantriniliprole $9.3 \%$ ZC (16.29thrips/plant), Buprofezin 15\% + Acephate 35\% WP(16.9 thrips/plant). All newer insecticides were found more efficient than bio pesticides. Among bio pesticides Azadirachtin 300 PPM and Karanj oil + Neem Oil recorded (20.99 thrips/plant) and 21.98 (thrips /plant) respectively. Both were found on par with Karanj oil having (22.11 thrips /plant). Highest thrips infestation was recorded in control (24.77thrips/ plant).

\section{Ten days after spraying}

After 10 days of spraying, Chlorantriniliprole $8.8 \%$ + Thiomethoxam $17.5 \%$ SC recorded lowest population (18.70 thrips/ plant) followed by Thiomethoxam 12.5\% + Lambdacyhalothrin 9.5\% ZC (20.08 thrips/plant), Lambda-cyhalothrin $\quad 4.6 \% \quad+$ Chlorantriniliprole $\quad 9.3 \% \quad \mathrm{ZC}(21.13$ thrips /plant), Buprofezin 15\% + Acephate 35\% WP(21.40 thrips/plant). From bio pesticides, Azadirachtin 300 PPM found 24.51thrips/ plant followed by Karanj oil and mixture of Karanj oil + Neem oil recorded 25.27 and 26.87 thrips/ plant respectively. With 29.41 thrips /plant control (water spray) found most susceptible for thrips infestation. On the basis of data observed in three, seven and ten days after spraying in each spray, treatment
Chlorantriniliprole $8.8 \%+$ Thiomethoxam $17.5 \% \mathrm{SC}$ at the rate $4 \mathrm{mg}$ per ten liters was more effective than other treatments. Besides control mixture of Karanj oil + Neem oil found less efficient among treatments. The order of effectiveness of these treatments in descending order was Chlorantriniliprole $8.8 \%$ + Thiomethoxam $17.5 \%$ SC > Thiomethoxam $12.5 \%$ + Lambda-cyhalothrin $9.5 \% \mathrm{ZC}>$ Lambda-cyhalothrin $\quad 4.6 \% \quad+$ Chlorantriniliprole 9.3\% ZC > Buprofezin 15\% + Acephate 35\% WP > Azadirachtin 300 $\mathrm{PPM}>$ Karanj oil > Karanj oil + Neem oil > Control. Treatment Chlorantriniliprole $8.8 \%$ + Thiomethoxam $17.5 \%$ SC and Thiomethoxam $12.5 \%$ + Lambda-cyhalothrin 9.5\% ZC both contain Thiomethoxam which is found more efficient. The results are conformity with that of Samot et al., (2017), who found that Thiomethoxam was effective insecticide against thrips. Similarly, Ghosh et al., (2009) reported that thiamethoxam, followed by acetamiprid, fipronil, clothianidin and oxydemeton methyl were effective insecticides against thrips which support the present findings. However, Patel et al., (2009) and Pandey et al., (2010) recorded lower thrips population in the plots treated with NSKE as we also found the same in the present findings.

The present investigations on bio-efficacy of newer insecticides and bio pesticides against thrips, Scirtothrips dorsalis Hood in Pomegranate suggest that after three, seven and ten days of spraying in each spray schedule the treatment viz., Chlorantriniliprole $8.8 \%$ + Thiomethoxam $17.5 \%$ SCat the rate of $4 \mathrm{mg}$ per ten liters was more effective than other treatments and could be used for the management of this pest in pomegranate.

\section{Acknowledgement}

The authors sincerely thanks Dr. Jyotsana Sharma, Director of pomegranate Research Block H-25 of ICAR-NRCP, Solapur, 
Maharashtra for conducting research experiments and Department of Entomology, Jawahar Lal Nehru Krishi Vishwa Vidyalaya, Jabalpur, Madhya Pradesh for providing the necessary facilities to conduct the investigations.

\section{References}

Evreinoffa, A.A., 1949. The Pomegranate. Fruits d' Outre Mer.4: 161-170.

Ghosh Amalendu, Chatterjee M.L., Chakraborti, K. and Samanta, A. 2009. Field evaluation of insecticides against chilli thrips (Scirtothrips dorsalis Hood). Annals of Plant Protection Science. 17(1):69-71.

NHB, Database, 2017-18. Horticultural
Statistics at a Glance. 2017.

Pandey, S.K., Mathur, A.C. and Srivastava, M. 2010. Management of leaf curl disease of chilli (Capsicum annuum L.). International Journal of Virology. 6:246-250.

Patel, B.H., Koshiya, D.J., Korat, D.M. and Vaishnav, P.R. 2009. Evaluation of some insecticides against chilli thrips, Scirtothrips dorsalis Hood. Karnataka Journal of Agricultural Sciences. 22(2): 327-330.

Samota, R.G., Jat, B.L. and Mamta Devi Choudhary, 2017. Efficacy of newer insecticides and biopesticides against thrips, Scirtothrips dorsalis Hood in chilli. Journal of Pharmacognosy and Phytochemistry. 6(4): 1458-1462.

\section{How to cite this article:}

Shinde, S. R., A. K. Bhowmick, A. K. Shukla and Kuldeep Sharma. 2019. Bio-efficacy of Newer Insecticides and Biopesticides against Thrips, Scirtothrips dorsalis Hood in Pomegranate. Int.J.Curr.Microbiol.App.Sci. 8(12): 1231-1237.

doi: https://doi.org/10.20546/ijcmas.2019.812.152 